\title{
SMALL TERRESTRIAL MAMMALS (SORICOMORPHA, CHIROPTERA, RODENTIA) FROM THE EARLY HOLOCENE LAYERS OF MALA TRIGLAVCA (SW SLOVENIA)
}

\section{MALI TERESTIČNI SESALCI (SORICOMORPHA, CHIROPTERA, RODENTIA) IZ ZGODNJEHOLOCENSKIH PLASTI MALE TRIGLAVCE (JZ SLOVENIJA)}

\author{
Borut TOŠKAN ${ }^{1}$
}

\begin{abstract}
UDC 903.4(497.4)"627":569.3

Borut Toškan: Small terrestrial mammals (Soricomorpha, Chiroptera, Rodentia) from the Early Holocene layers of Mala Triglavca (SW Slovenia)

At least 132 specimens belonging to no less than 21 species of small terrestrial mammals from the Boreal were identified within the finds from the Early Holocene sediments from Mala Triglavca (the Kras Plateau, SW Slovenia), namely Crocidura suaveolens, Sorex alpinus / araneus, S. minutus, Talpa cf. europaea, Barbastella barbastellus, Sciurus vulgaris, Cricetulus migratorius, Arvicola terrestris, Microtus agrestis / arvalis, M. subterraneus / liectensteini, Chionomys nivalis, Myodes glareolus, Dinaromys bogdanovi, Glis glis, Muscardinus avellanarius and Apodemus flavicollis / sylvaticus / agrarius / uralensis. This small mammal assemblage indicates that their habitat was presumably a mosaic of a mixed, predominantly deciduous forest, dotted with small meadows and some rocky substrate. A comparison of allochronous microfaunas from the Kras Plateau indicated a rapid faunistic change in the last 5,000 years.

Keywords: small mammals, Slovenia, Boreal, palaeoenvironment.
\end{abstract}

Izvleček

UDK 903.4(497.4)"627":569.3 Borut Toškan: Mali terestični sesalci (Soricomorpha, Chiroptera, Rodentia) iz zgodnjeholocenskih plasti Male Triglavce (JZ Slovenija)

V zgodnjeholocenskih sedimentih iz Boreala jame Mala Triglavca pri Divači so bili najdeni ostanki najmanj 132 primerkov malih sesalcev, ki pripadajo vsaj 21 vrstam: Crocidura suaveolens, Sorex alpinus / araneus, S. minutus, Talpa cf. europaea, Barbastella barbastellus, Sciurus vulgaris, Cricetulus migratorius, Arvicola terrestris, Microtus agrestis / arvalis, M. subterraneus / liectensteini, Chionomys nivalis, Myodes glareolus, Dinaromys bogdanovi, Glis glis, Muscardinus avellanarius and Apodemus flavicollis / sylvaticus / agrarius / uralensis. Tedanje združbe malih sesalcev kažejo na mozaičen tip habitata $z$ mešanimi, pretežno listopadnimi gozdovi in manjšimi travniki ter kamnišči. Primerjava $\mathrm{z}$ alohronimi mikrofavnami s Krasa je nakazala hiter favnistični obrat v zadnjih 5,000 letih.

Ključne besede: mali sesalci, Slovenija, Boreal, paleookolje.

\section{INTRODUCTION}

The Early Holocene small mammal fauna of Slovenia is poorly known. This is due to a small number of excavated sites, on the one hand, and to the fieldwork techniques used in the past that were far from meeting the modern standards, on the other. Concerning the latter, an important weak point of the field work methodology worth mentioning here is that the excavated sediments were not washed through sieves. Thus, in spite of numerous attempts to treat the excavated sites in an all-round manner, including faunal remains (Pohar 1984, 1986, 1990; Toškan \& Dirjec 2004, 2006), teeth and bones of small mammals were only rarely collected (e.g. Rakovec 1959, 1961; Pohar 1986, 1990) and never analyzed in details (for exception see Toškan \& Kryštufek 2004). In the case

\footnotetext{
${ }^{1}$ Institute of Archaeology SRC SASA, Novi trg 2, P.O. Box 306, SI-1001, Ljubljana, Slovenia, e-mail: borut.toskan@zrc-sazu.si Received/Prejeto: 20.05.2008
} 
of Mala Triglavca, however, the wet-sieving of the sediments yielded a relatively rich small mammal assemblage (NISP $=749$ ), which provide a good opportunity to obtain a deeper insight into the Early Holocene small mam- mal faunas of the Kras Plateau. The remains elaborated in this paper are those of Soricomorpha, Chiroptera and Rodentia.

\section{SITE, MATERIAL AND METHODS}

Mala Triglavca (herein after: M. Triglavca) is a pronounced ( $8 \mathrm{~m}$ wide, $6 \mathrm{~m}$ long, $1.8-0.8 \mathrm{~m}$ high) rock shelter in a small collapsed doline of the Divača karst (437 m a.s.l; Fig. 1). It was first described and measured for archaeological purposes by F. Leben (1988); he excavated there in 1979-1985, depositing the excavated sediments in the vicinity of the rock-shelter. On his initiative, I. Turk later wet-sieved $1,677 \mathrm{~kg}$ of the deposited sediment of the so-called Mesolithic horizon (Turk, 2004a), revealing also the small mammal remains elaborated in this paper. For the sake of reliability of the stratigraphic setting of the studied assemblage it was decided to completely remove all the recent sediment overlying the Mesolithic material before beginning to sample. That the bulk of the sediments in Leben's deposits presumably belong to the Mesolithic layer is confirmed by archaeological finds (Leben 1988; Turk \& Turk 2004). Based on the number $(\mathrm{N}=286)$ and type of the excavated stone artifacts, the available archaeological material is to be ascribed to the Sauveterrian-Castelnovian complex (ca. 8,000-6,000 B.C.; Turk \& Turk 2004), which corresponds to the Boreal palaeoclimatic period. In view of the above mentioned removal of the recent sediment deposited over the material of the so-called Mesolithic horizon as well as the relatively high number of collected stone artifacts datable to the Sauveterrian-Castelnovian complex, the same chronological frame is to be assumed also for the microfauna discussed below.

The small mammal material consists of teeth, maxillas, mandibles and postcranial remains, whereby the latter were not subjected to further analysis. The comparative recent and subfossil material (collections of the Natural History Museum of Slovenia and the Regional Museum Koper) originates mainly from Slovenia and adjacent regions of the Balkan Peninsula. Quantitative comparisons among taxa were based on the Number of Identified Specimens (NISP) and on the Minimum Number of Individuals (MNI); cf. Grayson (1984, 17 ff) for further details. Within the framework of the biometric analysis, the existence of statistically significant heterogeneity among individual samples was determined using the Scheffé test (StatSoft Inc. 2001). Allochronous small mammal faunas were compared by multidimen- sional scaling on the rectangular symmetric matrix of the Jaccard's coefficients of similarity. For measuring the percentage of species whose "temporal" ranges end within a chronologically distinct small mammal assem-

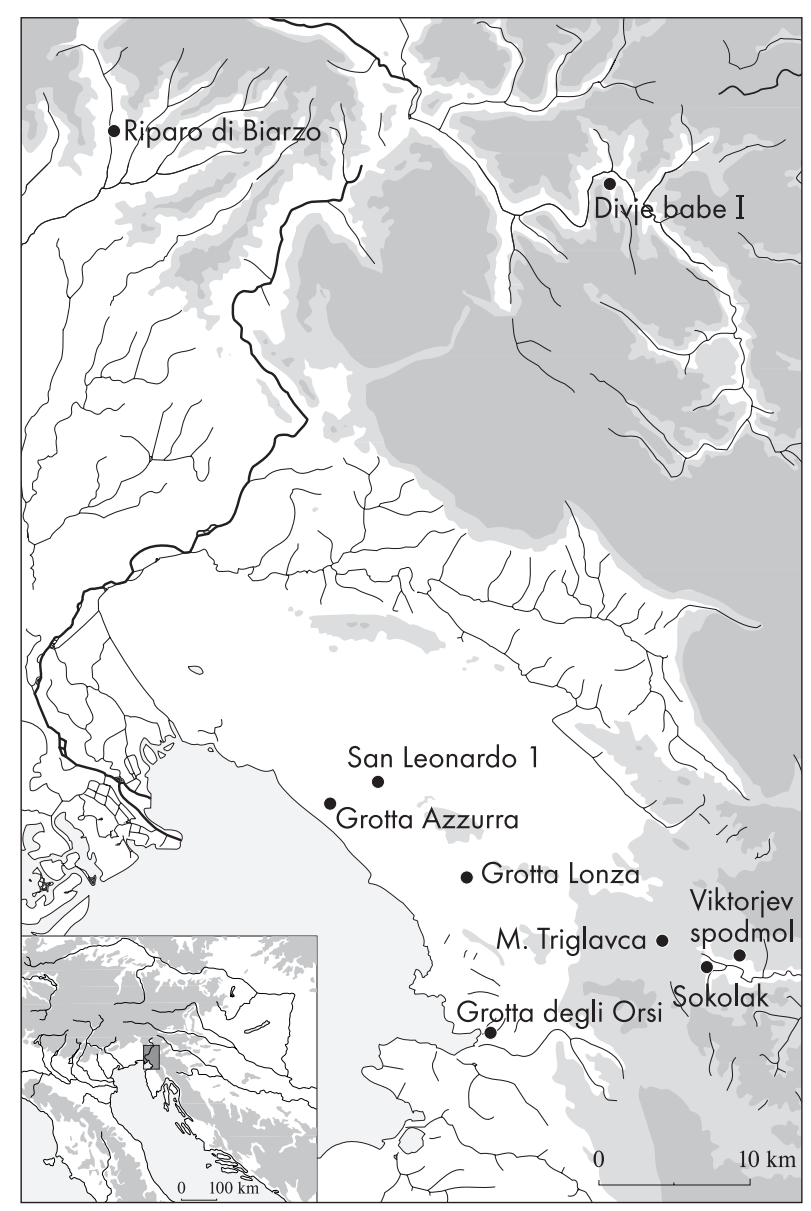

Fig. 1: Map of the Kras Plateau and the archaeological sites (dots) mentioned in the text.

blage, the Index of Faunistic Change (IFC) was used (cf. Hagmeier \& Stults 1964). The relative hospitality of (palaeo)habitats to micro mammals and the prevalence of environmental conditions needed to support each species was assessed by packing the presence-absence matrix to the state of maximum nestedness ( $c f$. Atmar 
\& Patterson 1993). Statistical calculations were run in StatSoft 2001 - Statistica for Windows (version 6.0) and in Nestedness temperature calculator programme (Stat Soft 2008).

Cheek-teeth are abbreviated as follows: P - premolars, M - molars; capital letters indicate the upper teeth and small letters the lower ones. The nomencla- ture of molars follows Van Der Meulen (1973; arvicolins) and Niethammer \& Krapp (1978 for murins and 1982 for cricetins). All dimensions are given in millimeters.

Subfossil microfaunal remains from M. Triglavca are kept at the Regional Museum Koper.

\section{RESULTS AND DISCUSSION}

\section{TAXONOMY}

The examined sample of the cave deposits yielded a total number of 980 molars, mandibles and maxillas of small mammals; 749 of these allowed identification at least to the generic level. The material belonged to not less than 132 specimens, ascribed to 21 species from six families. The share of rodents within the identifiable items exceeds 97 percent, while bats, on the other hand, are represented by only 4 specimens. All species in the sample are still extant and most still occur in Slovenia. The only exceptions are the grey hamster (Cricetulus migratorius), Martino's vole (Dinaromys bogdanovi) and the herb field mouse (Apodemus uralensis).

Taxonomy and nomenclature follow Wilson \& Reeder (2005).

Order: Shrews and moles (Soricomorpha)

Family: Shrews (Soricidae)

\section{Crocidura suaveolens (Pallas, 1811)}

The lesser white-toothed shrew is represented by four specimens: two fragmented rostrums and two isolated check-teeth (both P4). The rostrums contain several teeth, thus allowing the exclusion of the presence of C. leucodon and C. russula due to the shape of the $4^{\text {th }}$ upper premolar.

\section{Sorex minutus Linnaeus, 1766}

Two mandibles belong to the pygmy shrew. Both specimens are fragmented, thus no measurements could be taken. The pygmy shrew occurs in a wide range of habitats, depending on latitude and elevation (Hutterer 1999).

\section{Sorex alpinus / araneus}

A fragmentary mandible of a Sorex shrew does not allow identification to the species level. It belongs either to the alpine (Sorex alpinus Schinz, 1837) or the common shrew (S. araneus Linnaeus, 1758). Both species are already known from the Early Holocene of the Kras Plateau (Toškan \& Kryštufek 2004, 116 f); the common shrew is represented also in the Upper Pleistocene layers of the Caverna degli Orsi/Medvedja jama cave (Boschian 1999-2000, 60).

\section{Family: Moles (Talpidae)}

\section{Talpa cf. europaea Linneaus, 1758}

Genus Talpa is represented by a small number of isolated teeth, which did not allow a reliable distinction between the common mole Talpa europaea and the blind mole T. caeca Savi, 1822. In spite of the size differences (with T. europaea being bigger), the ranges of the two overlap considerably. The best distinction was achieved on the basis of $\mathrm{m} 1$ and $\mathrm{m}^{2}$ dimensions. Since the length and breadth of the two available $\mathrm{m} 1$ from M. Triglavca lie within the range of the recent T. europaeus (thus exceeding the maximal values for recent T. caeca), only the presence of the common mole could be demonstrated for the Early Holocene sediments of this site (Fig. 2).

Order: Bats (Chiroptera)

Family: Evening bats and vesper bats (Vespertilionidae)

\section{Barbastella barbastellus (Schreber, 1774)}

Bats are represented by three isolated teeth and a fragmented rostrum (including a M3), of which only the latter allowed identification beyond the family level: it was ascribed to barbastelle. The species probably prefers upland and forest habitats, hibernating (usually solitary or in small groups) in caves, bunkers, tunnels or cellars (Urbańczyk 1999). 


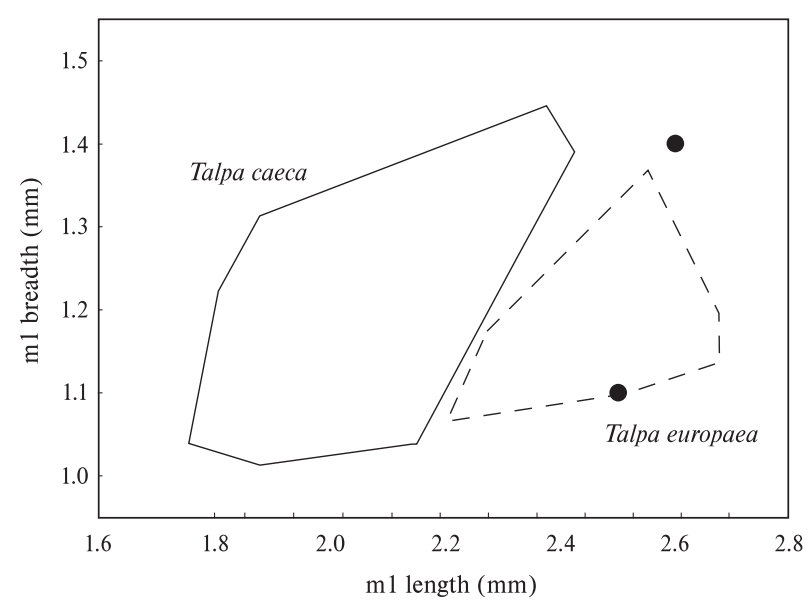

Fig. 2: Scatterplot of the breadth of the first lower molar ( 1 1) against its length in moles. Polygons enclose scores for 29 recent T. europaea from western Slovenia (broken line) and 30 recent T. caeca from Bosnia and Herzegovina, Montenegro and Kosovo (straight line). Dots indicate Early Holocene specimens from M. Triglavca.

Order: Rodents (Rodentia)

Family: Squirrels (Sciuridae)

\section{Sciurus vulgaris Linnaeus, 1758}

A mandible and 15 isolated check-teeth belong to the red squirrel. In terms of the length of the toothrow $(=9.5 \mathrm{~mm})$, the mandible from M. Triglavca lies within the range of recent S. vulgaris from Slovenia (Toškan, unpublished data).

As a large diurnal form red squirrel is quite rare in owl and raptor diet (Andrews 1990, $178 \mathrm{ff}$ ), hence it also rarely appears in fossil taphocoenoses (cf. Bon et al. 1991). Although juveniles fall prey to the mentioned predators relatively more often (Kryštufek 1991, 125), the numerousness of red squirrel teeth in the assemblage from $\mathrm{M}$. Triglavca deserves a brief comment. First of all it should be stressed that the material was carefully examined for possible presence of European souslik (Spermophillus citellus), which would well correspond to the appearance of Cricetulus, Crocidura or Microtus agrestis in the studied sample (Tab. 4) and which is a preferred prey for larger species of eagles. However, the crowns of upper molars are all nearly square, with the enamel tubercles and ridges being rather low, wherefore the squirrel material from M. Triglavca was conclusively ascribed to S. vulgaris (cf. Kryštufek \& Vohralík 2005, 22, 39 f). Such a conclusion is further corroborated by the morphology of the only preserved mandible, which is more robust than in souslik ( $c f$. Kryštufek \& Vohralík 2005, 39).

The most plausible explanation for the presence of red squirrel teeth in the examined sample seems thus to be linked to the representation of the stone marten (Martes martes) and wild cat (Felis silvestris) in the same assemblage (Pohar 1990, Tab. 1; Turk et al. 2004, 201). Apart from being known to (occasionally) produce bone assemblages (Andrews 1990, $41 \mathrm{f}$ ), these two species happen to be also red squirrel's main predators (Kryštufek 1991, 125).

Family: Hamsters, voles and lemmings (Cricetidae) Subfamily: Hamsters (Cricetinae)

\section{Cricetulus migratorius (Pallas, 1773)}

Four isolated molars (M1, $\mathrm{m} 1$ and two $\mathrm{m} 2$; Fig. 3: a, b) belong to the grey hamster. Molar dimensions lie within the range observed in the fossil dwarf hamster Allocricetus bursae (Schaub 1930) and are, as such, above the maximum for the recent and fossil $C$. migratorius (Toškan \& Kryštufek 2006, 102, and sources cited there). However, Mayhew (1978, 309 f) and Hír $(1993,28)$ warn that dimensions of isolated molars are not necessarily a suitable criterion for distinguishing between the two species. Besides, C. migratorius tends to be larger in fossil samples than in recent populations, with recent specimens showing extremely variable dimensions depending on climate (Popov 1994, 37). Although the taxonomic value of the discrete molar traits is argued to be similarly controversial by some authorities (e.g. Mayhew 1978, 309; Popov 1989, 57), it is worth noting that the posterior cingulum of M1 from M. Triglavca is well developed (as is to be found in C. migratorius) and not weak or absent as in A. bursae (Tchernov $1968,84)$. Taking the above into account, the material presented here was ascribed to the grey hamster, which is known to have inhabited the Kras Plateau at least till the Early Holocene (Bartolomei 1999-2000; Toškan \& Kryštufek 2006, 102).

\section{Subfamily: Voles and lemmings (Arvicolinae)}

\section{Arvicola terrestris (Linnaeus, 1758)}

Water vole is represented by three isolated second lower molars (Fig. 3: c). Their lengths are 2.2, 2.2 and $2.3 \mathrm{~mm}$, respectively, which lies within the range of both the Early Holocene A. terrestris from Viktorjev spodmol $(\mathrm{Me}=2.31$; range: $2.1-2.6 ; \mathrm{N}=12)$ and the recent water voles from Slovenia $(\mathrm{M}=2.34$; range: $1.98-2.58 ; \mathrm{N}=30$ ).

As currently accepted (Wilson \& Reeder 2005), the two long known ecological morphotypes of the all-embracing $A$. terrestris correspond to two biological species: the amphibious $A$. amphibious (Linaeus, 1758) and 


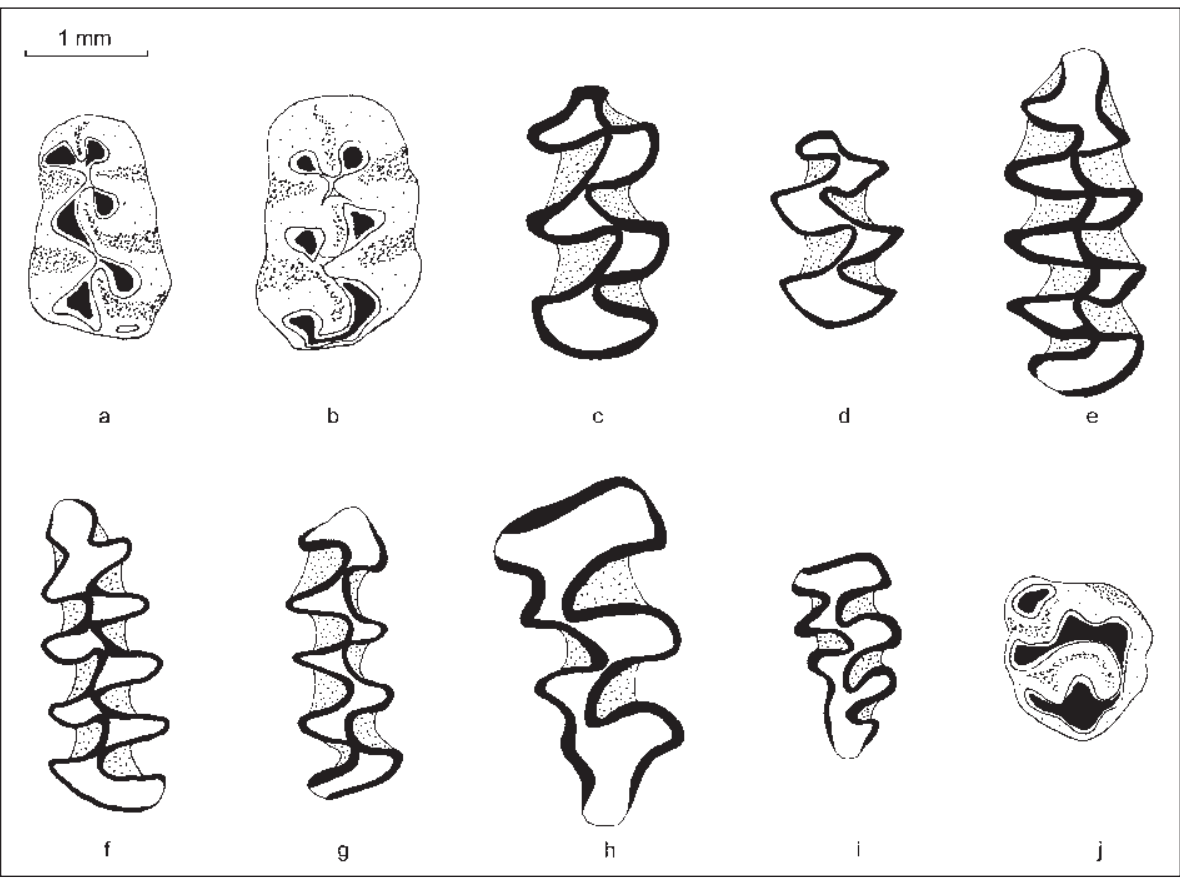

Fig. 3: Molars of hamsters (Cricetinae) and voles (Arvicolinae) from M. Triglavca. Cricetulus migratorius: (a) ; (b) . (c) $2^{\text {nd }}$ lower molar of Arvicola terrestris. (d) $2^{\text {nd }}$ upper molar of Microtus agrestis. (e) $1^{\text {st }}$ lower molar of Microtus $c f$. agrestis. $(f) 1^{\text {st }}$ lower molar of Microtus $c f$. arvalis. $(g)$ $1^{\text {st }}$ lower molar of Chionomys nivalis. (h) $3 r^{d}$ upper molar of Dinaromys bogdanovi. (i) Myodes glareolus, $3^{\text {rd }}$ upper molar: complex-typica morphotype. (j) $2^{\text {nd }}$ upper molar of Apodemus agrarius. Scale bar $=1 \mathrm{~mm}$.

the smaller fossorial A. schermann (Shaw, 1801). This renders a reliable determination of the here-presented material to the specific level impossible.

\section{Microtus agrestis / arvalis}

The shape of the anteroconid complex of $\mathrm{m} 1$, with separated dentine fields of triangles T4 and T5, allocated eleven arvicoline first lower molars from M. Triglavca either to the field vole Microtus arvalis (Pallas, 1779) or to the common vole $M$. agrestis (Linnaeus, 1761). A reliable

\begin{tabular}{|c|c|c|c|c|c|}
\hline Sample & $\boldsymbol{N}$ & $\boldsymbol{M}$ & min.-max. & SD & \multicolumn{2}{|c|}{ Homogeneous sets } \\
\hline 1 & 45 & 3.03 & $2.77-3.47$ & 0.143 & $\mathrm{X}$ \\
\hline 2 & 45 & 2.68 & $2.42-2.95$ & 0.138 & $\mathrm{X}$ \\
\hline 3 & 55 & 2.69 & $2.32-3.15$ & 0.197 & $\mathrm{X}$ \\
\hline 4 & 6 & 2.68 & $2.39-2.90$ & -- & $\mathrm{X}$ \\
\hline
\end{tabular}

Tab. 1: Descriptive statistics for $m 1$ length in four samples of the Microtus agrestis / M. arvalis. Homogeneous sets are based on the Scheffé test. Samples: 1 - recent M. agrestis from central Slovenia (the Ljubljansko barje); 2 - recent M. arvalis from Slovenia (the Ljubljansko barje, Kranjska gora, the Julian Alps); 3 - Early Holocene specimens of both species from Viktorjev spodmol; 4 - Early Holocene specimens from M. Triglavca. The table gives sample size (N), arithmetic mean ( $M$; in the case of $M$. Triglavca substituted by the median), range (min.-max.) and standard deviation (SD). distinction between these two species is possible on the basis of M2, which has an additional postero-lingual triangle (T5) in $M$. agrestis. Note, however, that even this characteristic is subject to temporal and geographic variation (e.g. Kryštufek $1986,38)$. The find of a single M2 with the additional triangle T5 (Fig. 3: d) confirms beyond doubt the presence of the common vole in $\mathrm{M}$. Triglavca.

Species identity of the first lower molars was assessed by the method proposed by Nadachowski (1984). Triangles T4 and T5 are subequal in $M$. arvalis, while M. agrestis is characterized by a larger T5 in comparison to T4. Consequently, a quotient between the lengths of these two triangles (T4/T5), when plotted against the $\mathrm{m} 1$ length, distinguishes these two voles fairly reliably (Fig. 3: e, f). This approach confirmed the presence of both species in the subfossil material from M. Triglavca, with $M$. arvalis being slightly more abundant (Fig. 4). However, specimens within the polygon of the recent $M$. arvalis do not attain the higher values of the quotient T4/T5 and, despite a shorter molar, actually have the agrestis $\mathrm{m} 1$ morphotype. Interestingly, no such thing was observed in the much larger sample of subfossil $\mathrm{m} 1$ from the nearby Viktorjev spodmol (N = 68; Toškan \& Kryštufek 2004, Fig. 15.4).

Early Holocene specimens from M. Triglavca do not differ in $\mathrm{m} 1$ length from the roughly contemporaneous material from Viktorjev spodmol or from the recent $M$. arvalis from Slovenia. The recent $M$. agrestis from central Slovenia, on the other hand, is significantly larger (Tab. 1). 


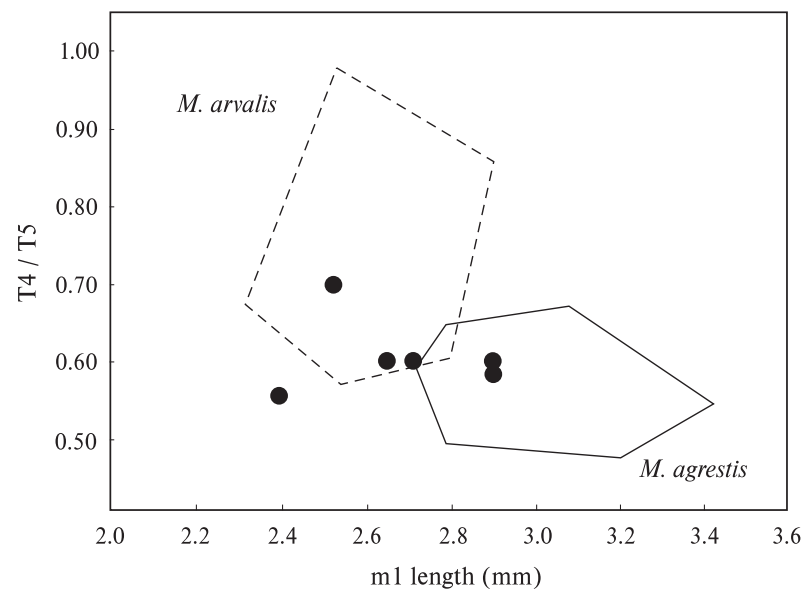

Fig. 4: Scatterplot of the quotient of triangles T4 with T5 as denominator (T4/T5) against the length of the first lower molar (m1) in Microtus agrestis / arvalis. Polygons enclose scores for 45 recent $M$. agrestis (straight line) and 45 recent $M$. arvalis (broken line), both from Slovenia (after Kryštufek 1997, Fig. 7.8). Dots indicate Early Holocene specimens from M. Triglavca.

\section{Microtus subterraneus / liechtensteini}

Pitymoid first lower molars $(\mathrm{N}=23)$ probably belong either to the common pine vole Microtus subterraneus (de Sélys-Longchamps, 1836) or the Liechtenstein's pine vole M. liechtensteini (Wettstein, 1927). The two species clearly differ in their chromosomal sets, but resemble each other most closely in their morphologies. Although Microtus liechtensteini tends towards a larger size, the lengths of isolated molars broadly overlap (Kryštufek 1997, 93). Morphometric characteristics of the $\mathrm{ml}$ in the material from M. Triglavca and the recent pine voles of both species are given in Fig. 5 and Tab. 2. The total length of $\mathrm{m} 1$ is significantly different between the three samples, with specimens from $\mathrm{M}$. Triglavca being the smallest and those of the recent $M$. liechtensteini the largest (Fig. 5). The picture is different for the length of the anterior part of $\mathrm{m} 1$ (sensu Spitzenberger et al. 2000, 474), where the subfossil material resembles the recent $M$. liechtensteini more than it resembles recent $M$. subterraneus ( $\mathrm{t}$-test: $\mathrm{p}=0.088-0.568$ vs. $\mathrm{p}=0.033$; Tab. 2). Despite this controversy, the great majority of $\mathrm{m} 1$ specimens from $\mathrm{M}$. Triglavca were ascribed to M. subterraneus. Namely, due to the intense interpopulational geographic variability in dental morphology of the two studied species ( $c f$. BrunetLecomte \& Kryštufek 1993; Spitzenberger et al. 2000), the total length of the first lower molar seems to have a greater taxonomic value in comparison to the length of its anterior part ( $c f$. Brunet-Lecomte \& Kryštufek 1993, Tab. 1).
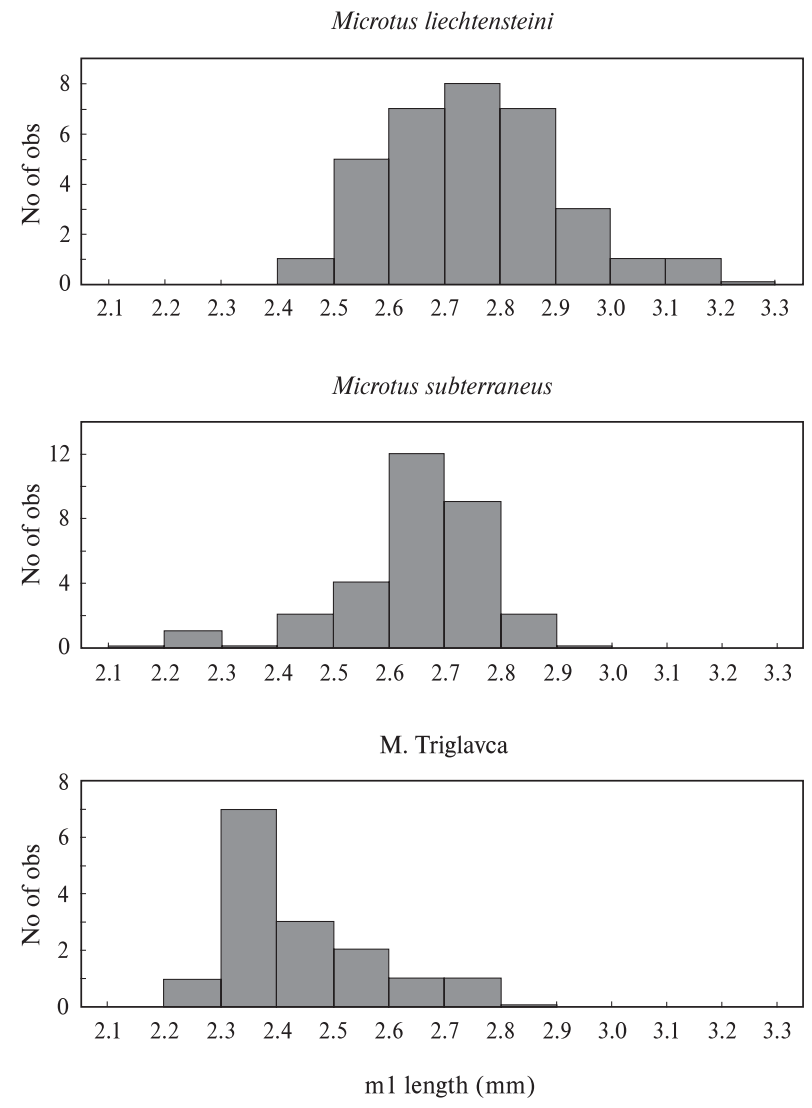

Fig. 5: Histogram of the length of the first lower molar (m1) in three samples of Microtus subterraneus / M. liechtensteini. Samples: 1 - recent M. liechtensteini from Slovenia; 2 - recent M. subterraneus from central Slovenia; 3 - Early Holocene specimens from $M$. Triglavca.

Microtus subterraneus and M. liechtensteini are extremely competing semifossorial species, so that their distribution is probably more restricted by the presence of each other than by the habitat (Kryštufek 1999). Palaeontological data indicate that in the Late Pleistocene and Early Holocene of the Kras Plateau and adjacent areas M. subterraneus was much more common than M. liechtensteini (Bartolomei 1996, 34 f; 2003, 13; Meluzzi et al. 1984, 122; Aguilar et al. 1998, 144; Toškan \& Kryštufek 2004, 124; 2007, 213). This observation is noteworthy, since only $M$. liechtensteini is known now to populate the studied area, while the range border of $M$. subterraneus is shifted into central Slovenia ca. $50 \mathrm{~km}$ towards the north-east (Kryštufek 1991, 147 ff). It thus seems evident that M. liechtensteini, after surviving the last one or two glaciations of the Alps in the refugial area(s) in the Dinaric Mountains (Haring et al. 2000, 237), re-invaded the southern parts of the Alps with the retreat of the ice and substituted the M. subterraneus in a part of its areal. 


\begin{tabular}{|l|c|c|c|}
\hline Sample & N & M & SD \\
\hline recent Microtus subterraneus (Slovenia and Croatia) & 226 & 0.524 & 0.013 \\
\hline recent Microtus liechtensteini (Slovenia and Croatia) & 156 & 0.521 & 0.017 \\
\hline recent Microtus liechtensteini (Carinthia, Austria) & 16 & 0.523 & 0.017 \\
\hline recent Microtus liechtensteini (E Tyrol, Austria) & 14 & 0.517 & 0.017 \\
\hline subfossil M. subterraneus / liechtensteini (M. Triglavca) & 13 & 0.513 & 0.020 \\
\hline
\end{tabular}

Tab. 2: Descriptive statistics for the anterior part (AP) of $m 1$ in five samples of Microtus subterraneus / M. liechtensteini. The table gives sample size $(N)$, arithmetic mean $(M)$ and standard deviation (SD). Data for the pine voles from Slovenia and Croatia is given in Brunet-Lecomte \& Kryštufek (1993, Tab. 1) and that for the pine voles from Austria in Spitzenberger et al. (2000, Tab. 4). For the definition of the anterior part (AP) of $m 1$ see Spitzenberger et al. (2000).

\section{Chionomys nivalis (Martins, 1842)}

Snow vole is represented by two isolated first lower molars, one of which is fragmented. The length of the other is $2.8 \mathrm{~mm}$, which lies within the range of both the recent $C h$. nivalis from the Julian Alps and the subfossil conspecifics from Viktorjev spodmol (Toškan \& Kryštufek 2004, Tab. 15.3). Both $\mathrm{m} 1$ are of the "nivalid" morphotype (sensu Kryštufek 1990, 127; Fig. 3: g). The same morphotype dominates also in the recent $\mathrm{Ch}$. $\mathrm{ni}$ valis samples from the Eastern Alps and the Dinarides, respectively (Kryštufek 1990, 127), as well as in the Early Holocene material from Viktorjev spodmol (Toškan \& Kryštufek 2004, 120) and the Late Pleistocene assemblage from Divje babe I (Toškan \& Kryštufek 2007, 197).

Paleontological data indicate that during the Late Pleistocene the snow vole was widespread mostly in the northern parts of the Balkan Peninsula (Terzea 1972; Fladerer 2000, 203; Rabeder 2004, 57; Toškan \& Kryštufek 2007, 211 f), including the Kras Plateau (Bon et al. 1991; Boschian 1999-2000, 60; Bartolomei 2003, 13). From the latter area many Early Holocene records are also known (Rakovec 1959, 300; Cremonesi et al. 1984, 29; Meluzzi et al. 1984, 122; Montagnari Kokelj 1984, 212; Toškan \& Kryštufek 2004, 120).

Dinaromys bogdanovi (Martino et Martino, 1922)

\begin{tabular}{|c|c|c|c|c|c|}
\hline Sample & $\boldsymbol{N}$ & $\boldsymbol{M}$ & min.-max. & SD & \multicolumn{2}{|c|}{ Homogeneous sets } \\
\hline 1 & 104 & 2.29 & $1.79-2.60$ & 0.196 & $\mathrm{X}$ \\
\hline 2 & 112 & 2.37 & $1.98-2.93$ & 0.147 & $\mathrm{X}$ \\
\hline 3 & 11 & 2.46 & $2.27-2.58$ & -- & $\mathrm{X}$ \\
\hline
\end{tabular}

Tab. 3: Descriptive statistics for $m 1$ length in three samples of Myodes glareolus. Homogeneous sets are based on the Scheffé test. Samples: 1 - recent M. glareolus from Slovenia; 2 - Early Holocene M. glareolus from Viktorjev spodmol; 3 - Early Holocene M. glareolus from M. Triglavca. The table gives sample size ( $N)$, arithmetic mean ( $M$; in the case of $M$. Triglavca substituted by the median), range (min.-max.) and standard deviation (SD). Data for bank voles from Viktorjev spodmol is given in Toškan \& Kryštufek (2004, Tab. 15.5).
Martino's vole is represented by a single third upper molar (length: $2.8 \mathrm{~mm}$; Fig. 3: h). The species now lives only in a small part of the historical range of the genus Dinaromys and has one of the smallest ranges amongst the recent European rodents (Kryštufek et al. 2007, 1221 f). Although Slovenia and NE Italy lay outside the actual range of the Martino's vole, the areas know several Late Pleistocene records of this species (Petrov \& Todorović 1982, 203; Aguilar et al. 1998, Tab. 1; Boschian 1999-2000, Tab. 2; Bartolomei 2003, Tab. 1). Moreover, the tooth from M. Triglavca and those from the nearby Viktorjev spodmol ( $\mathrm{N}=3$; Toškan \& Kryštufek 2004, 124 f) demonstrate that Martino's vole inhabited the Kras Plateau at least till the Early Holocene. The fairly recent shrinkage in the species range (i.e. ca. $130 \mathrm{~km}$ in the last ca. 10,000 years) might be a consequence of the penetration of the snow vole into the range of the Martino's vole in the Dinarides at some point during the Holocene (fossil records of Ch. nivalis in Dinaride Range are scarce; Mauch Lenardić 2005). This process is possibly still on-going, presumably resulting in the range shrinkage of the more ancient of the two rock-dwelling voles (Kryštufek et al. 2007, 1230).

\section{Myodes glareolus (Schreber, 1780)}

Bank vole is by far the best represented vole species in the material from M. Triglavca (Tab. 4). Such frequency partly reflects the fact that each bank vole's molar (and not just $\mathrm{m} 1$ as in most other voles) could be ascribed to this species due to the characteristic shape of the enamel pattern as well as by its rooted condition. Anyhow, there is no doubt that $M$. glareolus was indeed one of the better represented voles at M. Triglavca and in the fauna of the time on the Kras Plateau in general. This is further corroborated by its presence in the taphocoenoses from several other Early Holocene sites in the area (Rakovec 1959, 299; Meluzzi et al. 1984, 121; Bartolomei 1996, Tab. 1; Toškan \& Kryštufek 2004, $121 \mathrm{ff}$ ).

The first lower molars from M. Triglavca do not 
differ significantly in length from the contemporaneous specimens from Viktorjev spodmol, but are significantly longer than in the recent bank voles from Slovenia (Tab. 3). The prevailing M3 $(\mathrm{N}=9)$ morphotype is the complex one $(\mathrm{N}=6)$, mainly its typical variant $(\mathrm{N}=3$; Fig. 3: i). The same condition is characteristic of the recent bank voles from Slovenia as well as of the subfossil material from Viktorjev spodmol.

\section{Family: Dormice (Gliridae)}

Glis glis (Linnaeus, 1766)

Edible dormouse is represented by 290 specimens, mostly isolated check-teeth. Length of first lower molars fit the range for recent G. glis from Slovenia (t-test: $\mathrm{p}=0.976$ ). Having said that, the specimens from $M$. Triglavca had significantly narrower $\mathrm{m} 1$ than the recent animals (t-test: $p=0.007$; Fig. 6). The same condition is characteristic of the subfossil edible dormice from Viktorjev spodmol, which thus closely resemble those from M. Triglavca (t-test: $\mathrm{p}=0.899$ ).

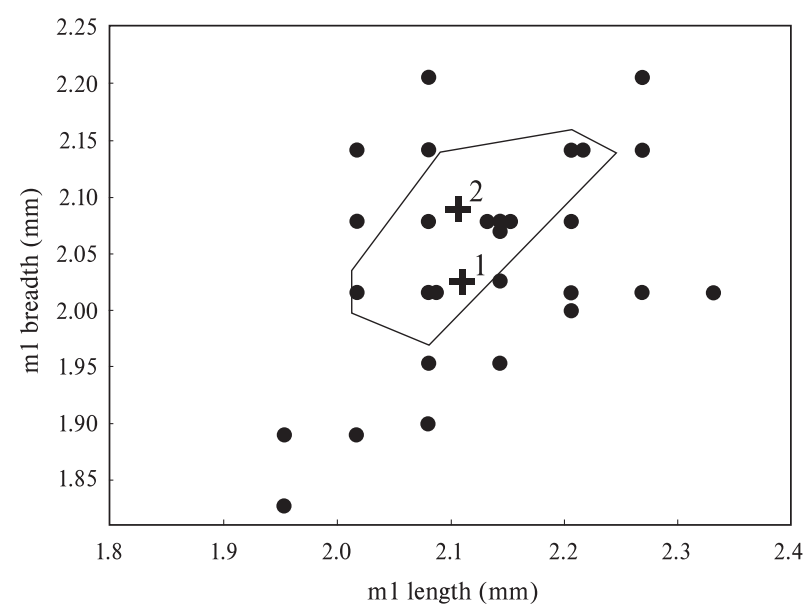

Fig. 6: Scatterplot of breadth of the first lower molar (m1) against its length in edible dormouse. The polygon encloses scores for 30 recent Glis glis from Slovenia. Dots indicate Early Holocene specimens from M. Triglavca. Crosses (+) indicate the arithmetic mean for Early Holocene material from M. Triglavca (1) and recent specimens from Slovenia (2).

Muscardinus avellanarius (Linnaeus, 1758)

An isolated first upper molar (M1) belongs to the common dormouse. The species is known to have inhabited the area at least from the Late Pleistocene onwards (Bon et al. 1991; Toškan \& Kryštufek 2007, 201).
Family: Mice and rats (Muridae)

Apodemus flavicollis / sylvaticus / agrarius / uralensis

The genus Apodemus is represented by 327 isolated teeth and mandible fragments, being thus by far the most abundant small mammal taxon in the taphocoenoses from M. Triglavca. On the basis of the size and morphology of the available specimens they were ascribed to four recent species: yellow-necked mouse A. flavicollis (Melchior, 1834), long-tailed field mouse A. sylvaticus (Linnaeus, 1758), striped field mouse A. agrarius (Pallas, 1771) and herb field mouse A. uralensis (Pallas, 1811). Apodemus agrarius is represented in the material by an isolated M2, which lacks the meso-labial tubercle t3 (Fig. 3: j); such a condition is diagnostic for the species (Böhme 1978, 368). The presence of $A$. uralensis was ascertained by the small size of an isolate M1 (length $\mathrm{x}$ breadth: $1.64 \times 1.13 \mathrm{~mm}$ ) and by its morphological traits: the cusp $\mathrm{t} 7$ is ridge-like, $\mathrm{t} 4$ is displaced posteriorly with respect to 6 , the tooth lacks a t12, the cusp $t 1$ lacks a spur and is not (yet) connected with $\mathrm{t} 2$ despite the rather advanced stage of wear (Fig. 7; cf. Filippucci et al. 1996, 7). Morphological differences in the remaining molars are slight and do not allow for a reliable determination to the level of species (Janžekovič \& Kryštufek 2004). Moreover, populations of A. sylvaticus, A. flavicollis, and A. agrarius are known to be characterized by a considerable size variation (Alcántra 1991). Nevertheless, the size of M1 allowed us to ascertain the presence of all three species (in addition to A. uralensis) in the assemblage from M. Triglavca, whereby A. flavicollis is the most common and $A$. agrarius the least (Fig. 8).

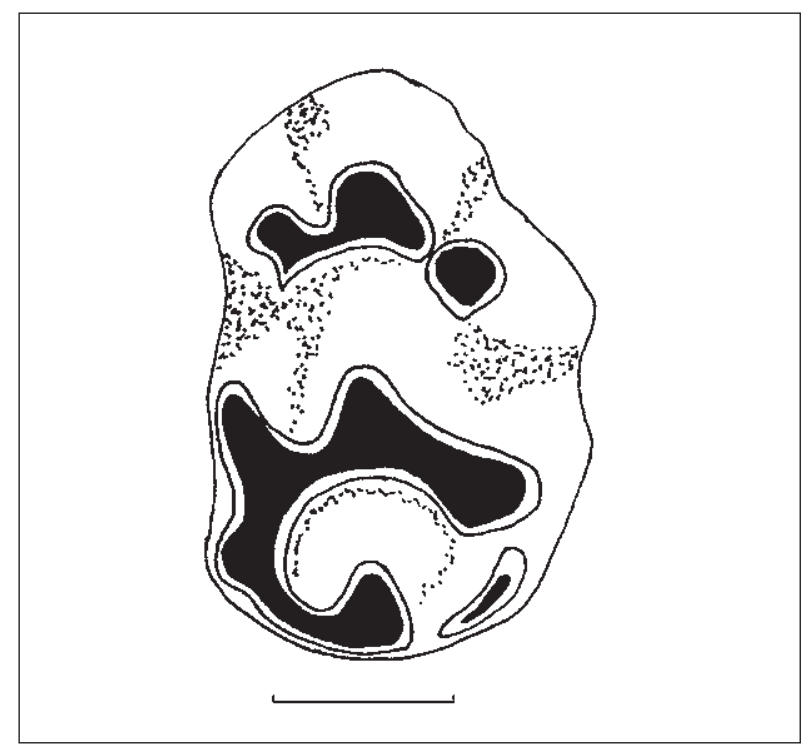

Fig. 7: First upper molar of the pygmy field mouse (Apodemus uralensis) from M. Triglavca. Scale bar $=0.5 \mathrm{~mm}$. 


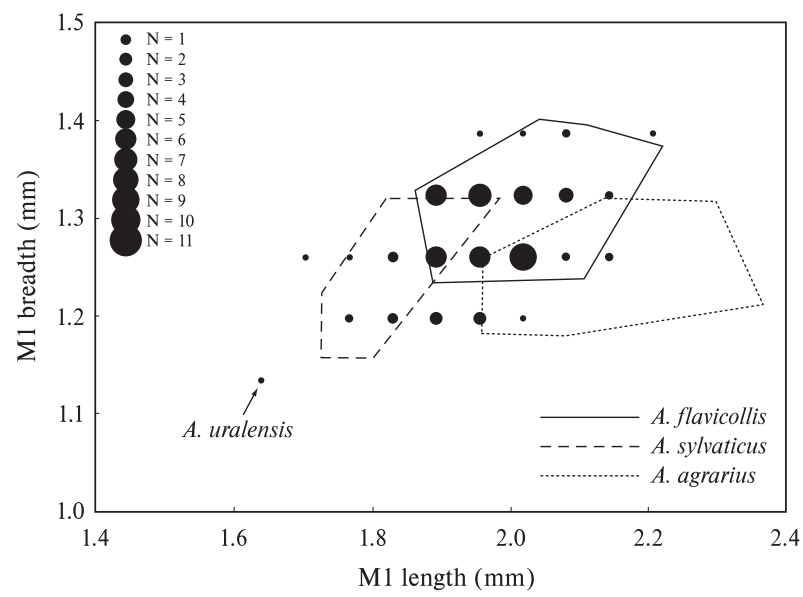

Fig. 8: Scatterplot of the breadth of the first upper molar (M1) against its length in wood mice. Polygons enclose scores for 35 recent A. flavicollis (straight line), 30 recent A. sylvaticus (broken line), both from central Slovenia (after Kryštufek 1997, Fig. 7.9), and 30 recent $A$. agrarius (dotted line) from SW Slovenia. Dots indicate Early Holocene specimens from M. Triglavca.

\section{TAPHOCOENOSIS}

The Minimum Number of Individuals (MNI) per taxon in the subfossil material from M. Triglavca is summarized in Tab. 4. Similarly as in the caves elsewhere, owls were evidently responsible for the bulk of accumulated bones and teeth. Among other things, the composition

\begin{tabular}{|l|c|c|c|c|}
\hline Taxon & NISP & $\%$ NISP & MNI & $\%$ MNI \\
\hline C. suaveolens & 4 & 0.5 & 3 & 2.3 \\
\hline S. minutus & 2 & 0.3 & 2 & 1.5 \\
\hline S. alpinus / araneus & 1 & 0.1 & 1 & 0.8 \\
\hline Talpa cf. europaea & 9 & 1.2 & 2 & 1.5 \\
\hline B. barbastellus & 1 & 0.1 & 1 & 0.8 \\
\hline S. vulgaris & 16 & 2.1 & 4 & 3.0 \\
\hline C. migratorius & 4 & 0.5 & 2 & 1.5 \\
\hline A. terrestris & 3 & 0.4 & 2 & 1.5 \\
\hline M. agrestis/arvalis & 12 & 1.6 & 7 & 5.3 \\
\hline M. subterraneus /liechtensteini & 23 & 3.1 & 13 & 9.8 \\
\hline Ch. nivalis & 2 & 0.3 & 1 & 0.8 \\
\hline D. bogdanovi & 1 & 0.1 & 1 & 0.8 \\
\hline M. glareolus & 53 & 7.1 & 9 & 6.8 \\
\hline G. glis & 290 & 38.7 & 16 & 12.1 \\
\hline M. avellanarius & 1 & 0.1 & 1 & 0.8 \\
\hline Apodemus sp. & 327 & 43.8 & 67 & 50.8 \\
\hline TOTAL & 749 & 100 & 132 & 100 \\
\hline
\end{tabular}

Tab. 4: Number of Identified Specimens (NISP) and Minimum Number of Individuals (MNI) in small mammal subfossil assemblage from M. Triglavca. of the sample thus reflects the preferences of the predator towards prey categories. Irrespective of this, the assemblage from $\mathrm{M}$. Triglavca is believed to reliably reflect environmental conditions in the vicinity of the cave, since the relatively large time scale of small mammal accumulation is supposed to compensate for most of the sampling bias.

\section{Palaeoenvironment}

No less than 21 species of small mammals were identified at M. Triglavca. Such pronounced species diversity indicates a mosaic structure of the habitat (cf. Janžekovič \& Čas 2001, 323 f) and a mild climate. The latter is further corroborated by the presence of the mole and the lesser white-toothed shrew, both being termophilous species. Nearly half of the determined specimens were ascribed to the genus Apodemus (43.8\% NISP, $50.8 \% \mathrm{MNI}$ ), with A. flavicollis being the most common (see above). Contrary to A. sylvaticus, which prefers open habitats, A. flavicollis is a typical forest dweller (Montgomery 1999). Forest-dwelling species are further represented by dormice (G. glis and $M$. avellanarius), red-toothed shrews (S. minutus and S. alpinus / araneus), Myodes glareolus and Sciurus vulgaris, comprising in total over two thirds of the total number of identified specimens / minimum number of individuals.

The share of small mammals that depend on open habitats is much smaller. Indicative of the latter are the voles of the genus Microtus ( $4.7 \%$ NISP, $14.9 \%$ MNI) and Cricetulus migratorius. Noteworthy is also the presence of Chionomys nivalis and Dinaromys bogdanovi, since both voles depend strictly on the availability of a rocky substrate to provide shelter in narrow fissures and caverns (Kryštufek 2004, 97). Overall, the landscape in the vicinity of $M$. Triglavca during the Early Holocene was probably a habitat mosaic of mixed, though predominantly deciduous forests (which is evident from the abundance of frugivorous dormice and yellow-necked field mouse), meadows and rocky sub- 
strate. Such a conclusion is consistent with the results of palynological studies (Toškan \& Kryštufek 2004, 130 f, and sources cited there).

A similar type of habitat is to be expected for the Kras Plateau in general. This can be inferred from the great resemblance of the local Early Holocene small mammal faunas ( $c f$. Cremonesi et al. 1984, 28 f; Meluzzi et al. 1984, 121 f; Bon et al. 1991; Toškan \& Kryštufek 2004). Differences in species richness between various taphocoenoses do not seem to be problematic in this respect, since they are to be ascribed to very different sample sizes. If the number of species per sample is adjusted for the size of the sample, the inter-site differences become much smaller if not negligible (Tab. 5).

The Early Holocene micromammal faunas from the Kras Plateau show a distinctive uniformity also in terms of the relative frequency of various small mammal species. This resemblance is best seen by comparing M. Triglavca and Viktorjev spodmol, which yielded the richest small mammal faunas in the area (Fig. 9). At the former, a slightly higher percentage of frugivorous Apodemus flavicollis (as the most common wood mice in the two assemblages) and Glis glis has been observed,

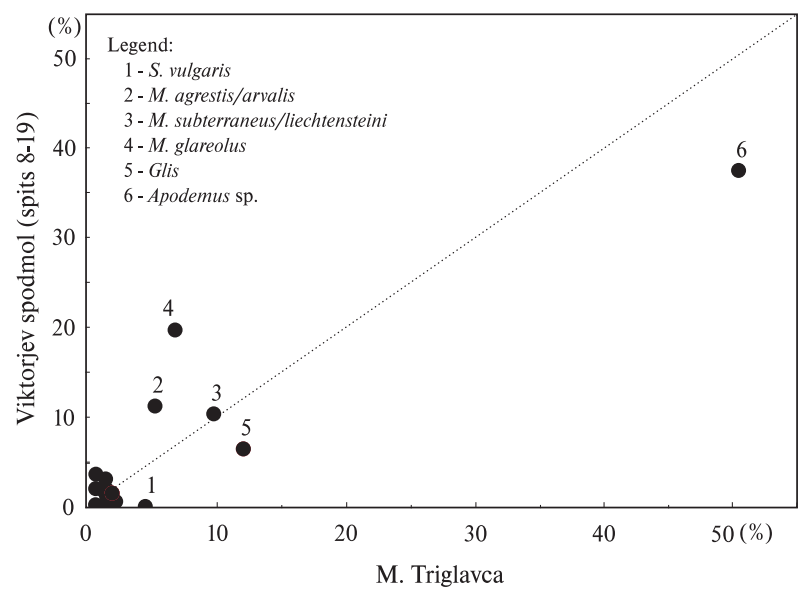

Fig. 9: Shares of various small mammal species in the assembalges from M. Triglavca and Viktorjev spodmol. In the case of the latter only remains from the Early Holocene spits 8-19 are shown.

Comparison of allochronous small mammal faunas

The comparison of micromammal assemblages from the Early Holocene layers of Viktorjev spodmol, Grotta Azzurra/Pečina na Leskovcu and Grotta Lonza/"Pečina Lonza" with the recent sympatric fauna showed substantial differences. Namely, the subfossil material resembled more closely the recent fauna from central Slovenia than the modern fauna of the Kras Plateau (Toškan \& Kryštufek 2004, 132 f).

The comparison above can be further extended by including the subfossil material from M. Triglavca and with the share of Myodes glareolus and Microtus agrestis / arvalis being slightly lower than at Viktorjev spodmol. Since the taphocoenosis from the latter site is expected to be geologically slightly older than the material from M. Triglavca (Turk 2004b, 208), these differences could reflect a further expansion of forests at the end of the Boreal (with a stronger presence of deciduous trees in them) due to progressive global warming. Nevertheless, the differences in the share of various rodent species between each of the two sites usually being low (range: $1.1 \%-13.0 \%$; $\mathrm{Me}=1.6 \%$ ), the possibility of them being fortuitous should also be taken into account. three fossil assemblages from Caverna degli Orsi/Medvedja jama and San Leonardo 1/Sveti Lenart 1 caves, which provides an opportunity to obtain deeper insights into the Late Pleistocene/Holocene small mammal faunas from the Kras Plateau (Fig. 10). Worth noting in this sense is the assemblage from the seven uppermost spits at Viktorjev spodmol, which is archaeologically dated to the castellieri period (ca. 1,600-600 B.C.; Turk \& Velušček 2004). It lies between the two available Early Holocene assemblages, on the one side, and the owl pellet sample collected at the entrance to the nearby Sokolak Cave, on the other. Such a position is indicative of the progressive transition of the local species-rich Early Holocene microfauna towards the impoverished fauna inhabiting the north-eastern Adriatic coast today ( $c f$. Li- 


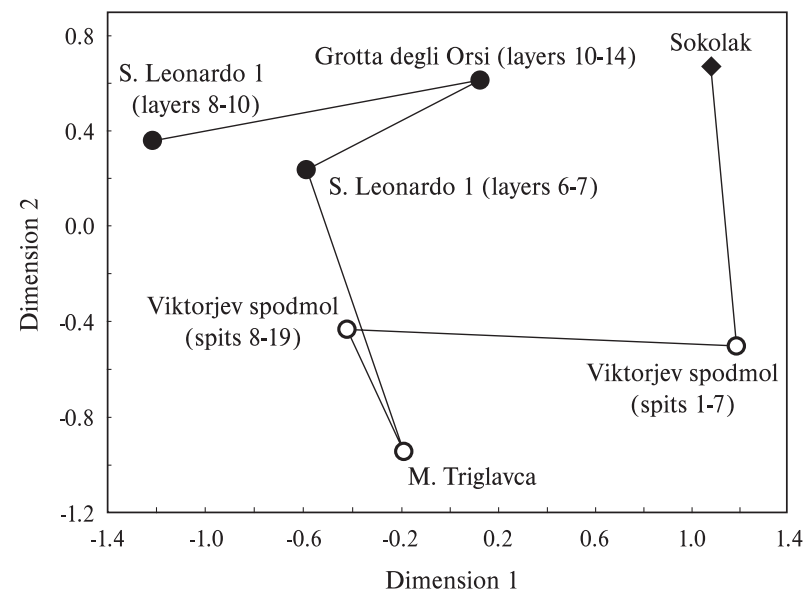

Fig. 10: Final distribution of the matrix derived from multidimensional scaling of Jaccard coefficients for three fossil (dots), three subfossil (open circles) and one recent (diamond) small mammal assemblages (bats excluded) from the Kras Plateau (stress $<0.1$ ). The line connects temporally subsequent assemblages. Species "pairs" Talpa caeca / T. europaea, Microtus agrestis / M. arvalis, Microtus subterraneus / M. liectensteini and Apodemus flavicollis / A. sylvaticus are treated as single taxa. Assemblages: San Leonardo 1/Sveti Lenart 1: layers 8-10 (Early Glacial $\approx$ OIS 5a-5d), layers 6-7 (end of Pleniglacial II $\approx$ OIS 2; Bartolomei 2003); Caverna degli Orsi/Medvedja jama (Early Glacial/Pleniglacial I $\approx$ OIS 5/OIS 4; Boschian 19992000); Viktorjev spodmol: spits 8-19 (Early Holocene), spits 17 (Middle Holocene; Toškan \& Kryštufek 2004); M. Triglavca (Early Holocene) and Sokolak (recent; Lipej \& Gjerkeš 1996). For locations of various sites see Fig. 1.

pej \& Gjerkeš 1996; Karajić \& Kryštufek 1999; Kryštufek \& Lipej 2002). Due to this impoverishment, the Early Holocene faunas of M. Triglavca and Viktorjev spodmol resemble more closely the fossil assemblages from the caves of San Leonardo 1/Sveti Lenart 1 and Grotta degli Orsi/Medvedja jama than the modern sympatric fauna. It is otherwise in the inland regions, where the list of recent fauna contains more or less the same micromammal taxa as during the Late Pleistocene/Early Holocene (cf. Janžekovič \& Čas 2001 vs. Rabeder 2004; Brajković et al. 2007).

Similar conclusions can be inferred from IFC values calculated for nine chronologically distinct small mammal assemblages from the Kras Plateau (Fig. 11). The faunal heterogeneity is most marked precisely at the transition between the subfossil and recent faunas (IFC $=50.0 \%$ ), indicating a period of relatively rapid faunistic change. It seems unlikely that such a high IFC value could be a consequence of different sample sizes (see Fig. 11). Instead, it is rather ascribable to the increased clearance, burning and grazing in the last millennia, which led to a local extirpation of many once widespread small mammal species. The result of this man-driven environmental degradation is a remnant fauna consisting mainly of a few widespread ubiquists, plus semi-fossorial or geophilic specialists (both groups including synanthropic or human commensal forms; Kryštufek \& Griffiths 1999, 175). It is thus not surprising that the comparison between the assemblage from M. Triglavca and a modern owl pellet sample collected some $50 \mathrm{~km}$ to the north (NISP $=410$; Kryštufek 1997, Tab. 7.9) yielded a much lower IFC value than the comparison between the assemblage from M. Triglavca and the modern owl pellet sample from the nearby Sokolak Cave (IFC $=25.0 \%$ vs. IFC = $50.0 \%$; see Fig. 11).

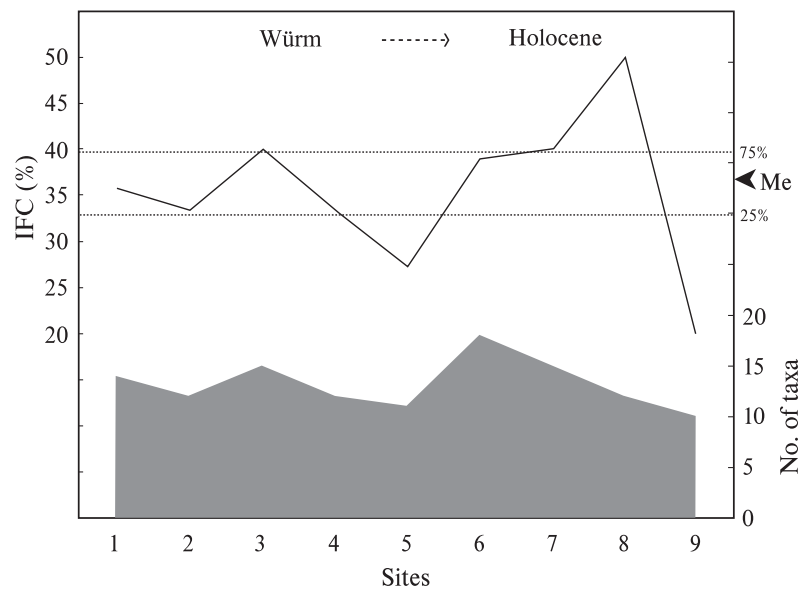

Fig. 11: Values of the Index of Faunistic Change (IFC) calculated for five fossil, three subfossil and one recent small mammal assemblages (bats excluded). Also shown is the number of taxa per assemblage. Species "pairs" Talpa caeca / T. europaea, Microtus agrestis / M. arvalis, Microtus subterraneus / M. liectensteini and Apodemus flavicollis / A. sylvaticus are treated as single taxa. Assemblages: 1 - San Leonardo 1/Sveti Lenart 1: layers 810 (Early Glacial; Bartolomei 2003); 2 - Caverna degli Orsi/Medvedja jama: layers 10-14 (Early Glacial/Pleniglacial I; Boschian 1999-2000); 3 - Divje babe I: facies A and B (Interpleniglacial $\approx$ OIS 3; Toškan and Kryštufek 2007); 4 - San Leonardo 1/Sveti Lenart 1: layers 6-7 (end of Pleniglacial II; Bartolomei 2003); 5 - Riparo di Biarzo/Pečina pri Bjarču: layers 5A-5C (Alleröd; Bartolomei 1996); 6 - Viktorjev spodmol: spits 8-19 (Early Holocene; Toškan \& Kryštufek 2004); 7 - M. Triglavca; 8 - Viktorjev spodmol: spits 1-7 (Middle Holocene; Toškan \& Kryštufek 2004) and 9 - Sokolak (recent; Lipej \& Gjerkeš 1996). For location of various sites see Fig. 1.

The above thesis of many once widespread small mammal species having gone locally extinct in the last millennia seems to be further corroborated by the results obtained by packing the presence-absence matrix for small mammal taxa represented in the above mentioned nine assemblages to a state of maximum nestedness. The method consists in ranking the differential hospitality of 
the sites (habitats) from most to least, starting at the top of the matrix; likewise, the prevalence and width of species' niches are ordered from the left (Atmar \& Patterson 1993). In our case the lowermost position in the packed matrix is occupied by the modern owl pellet sample from Sokolak, indicating that the relative hospitability of the present day Kras Plateau area to small mammals is lower relative to earlier periods (Fig. 12). The prevalence of environmental conditions needed to support the species under study seems to have been reduced also during the formation of assemblages from S. Leonardo / Sv. Lenart (layers 6-7) and Viktorjev spodmol (spits 1-7). While in the former case the observed results can be satisfactorily explained by the extremely harsh climatic conditions during the Pleniglacial II, the low relative hospitality of the Kras Plateau area during the Middle Holocene seems to be ascribable mainly to increased man-driven environmental degradation from the Neolithic Period on (Culiberg 1995, 212; Andrič \& Willis 2003, 818 f).

Contrary to the situation over the last 5,000 years, the Pleistocene-Holocene boundary on the Kras Plateau doesn't seem to have been characterized by a similarly rapid turnover in species composition (Fig. 11). It is true that the scarcity of published data on fossil small mammal faunas from the studied area does not allow for the construction of a continuous record for the entire Würm. However, the relatively low IFC values $(<40 \%$; see Fig. 11) are not surprising, since the refugium south of the

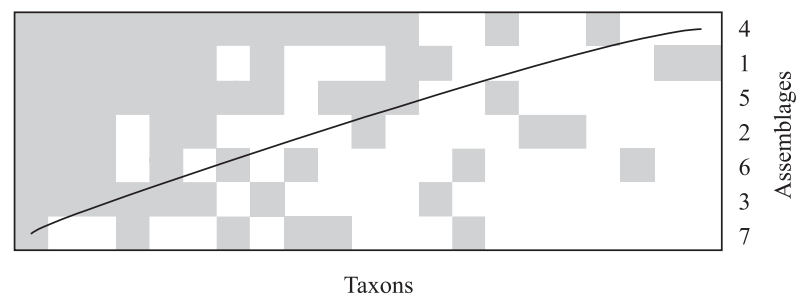

Fig. 12: Presence-absence matrix calculated for five fossil, three subfossil and one recent small mammal assemblage (bats excluded) packed to a state of maximum nestedness. The matrix fill and temperature equal $34.12^{\circ}$ and $45.5 \%$, respectively. The probability that the observed distribution pattern might be randomly produced is below the level of statistical significance $(p<$ 0.05). Species "pairs" Talpa caeca / T. europaea, Microtus agrestis / M. arvalis, Microtus subterraneus / M. liectensteini and Apodemus flavicollis / A. sylvaticus are treated as single taxa. Assemblage labels as in Fig. 11.

Alps has already been inhabited by forest-associated mammals in the Late Pleistocene ( $c f$. Toškan \& Kryštufek 2007, $206 \mathrm{f}$ ). Besides, the use of similarly scarce data as for the Kras Plateau did not prevent Toškan \& Kryštufek (2007, Fig. 10.7) from detecting a sharp contrast between the Late Pleistocene and (Early) Holocene small mammal faunas to the north of the Alpine glacier, where the replacement of boreal and steppe species by recent forest-dwellers seems to have occurred only towards the end of the Pleistocene.

\section{CONCLUSIONS}

The relatively rich small mammal fauna from M. Triglavca closely resembles other Early Holocene assemblages from the Kras Plateau both in terms of species richness and the share of individual taxa. The PleistoceneHolocene boundary was not characterized by extensive turnover in species composition. Contrary to this, a rapid faunistic change seems to have occurred during the last five millennia (Fig. 11). It is ascribable to the man-driven habitat degradation (cf. Kryštufek \& Griffiths 1999, 175) that contributed to a rapid decrease in the density of continental species, which were not adequately replaced. On the other hand, local extinction in SW Slovenia of at least two species (Cricetulus migratorius, Dinaromys bogdanovi) cannot be explained in the same way (see also Toškan \& Kryštufek 2004). It seems that habitat degradation was the most important, but not the only clue which shaped the small mammal species composition along the north-eastern Adriatic coast during the Holocene.

\section{ACKNOWLEDGMENTS}

I am most grateful to Dr. Ivan Turk and Janez Dirjec, who made it possible for me to study the subfossil material from M. Triglavca. Dr. Turk also provided critical comments on an earlier draft as did the reviewer (Ivan
Horáček). I thank Andreja Maver who improved the English and style as well as Mateja Belak and Drago Valoh who helped create graphics. 


\section{REFERENCES}

Aguilar, J.-P., Crochet, J.-Y., Krivic, K., Marandat, B., Michaux, J., Mihevc, A., Sigé B. \& S. Šebela, 1998: Pleistocene small mammals from some karstic fillings of Slovenia - preliminary results.- Acta carsologica, 27, 2, 141-150, Ljubljana.

Alcántra, M., 1991: Geographical variation in body size of wood mouse Apodemus sylvaticus L. - Mammal Review, 21, 143-150, Oxford.

Andrews, P., 1990: Owls, caves and fossils. Predation, preservation and accumulation of small mammal bones in caves, with an analysis of the Pleistocene cave faunas from Westbury-sub-Mendip, Somerset.UK Natural History Museum, London.

Andrič, M. \& K.J. Willis, 2003: The phytogeographical regions of Slovenia: a consequence of natural environmental variation or prehistoric human activity?Journal of Ecology, 91, 807-821, Oxford.

Atmar, W. \& B.D. Patterson, 1993: The measure of order and disorder in the distribution of species in fragmented habitat.- Oecologia, 96, 373-382, Berlin.

Bartolomei, G., 1996: Indicazioni paleoecologiche e paleoclimatiche.- In: Guereschi, A. (ed.), Il sito preistorico del Riparo di Biarzo (Valle del Natisone, Friuli), Pubblicazioni del Museo Friulano di Storia Naturale, 39.- Museo Friulano di Storia Naturale, 31-38, Udine.

Bartolomei, G., 1999-2000: Un piccolo criceto nell'Olocene inferiore della Grotta degli Zingari nel Carso Triestino.- Atti della Società per la Preistoria e Protostoria della Regione Friulli-Venezia Giulia, 12, 7 14, Trieste.

Bartolomei, G., 2003: Indicazioni paleoecologiche e paleoclimatiche sui depositi della Grotta di San Leonardo 1 nel Carso di Trieste (Samatorza, Aurisina).Atti della Società per la Preistoria e Protostoria della Regione Friuli-Venezia Giulia, 14, 7-24, Trieste.

Böhme, W., 1978: Apodemus agrarius (Pallas, 1771) Brandmaus.- In: Niethammer, J. \& F. Krapp (eds.), Handbuch der Säugetiere Europas, Band 1 - Akademische Verlagsgesellschaft, 368-381, Wiesbaden.

Bon, M., Piccoli, G. \& B. Sala, 1991: I giacimenti Quaternari di vertebrati fossili nell'Italia nord-orientale.- Memorie di Scienze Geologiche, 43, 185-231, Padova.

Boschian, G., 1999-2000: Early Upper Pleistocene lithic industry from Caverna degli Orsi near S. Dorligo della Valle (North-Eastern Italy).- Atti della Società per la Preistoria e Protostoria della Regione FriulliVenezia Giulia, 12, 55-66, Trieste.
Brajković, D., Mauch Lenardić, J. \& P.T. Miracle, 2007: The Upper Pleistocene refugium in Croatia.- In: Catto, N.R., van Kolfschoten, T. \& Rutter, N. (eds.), The tropics: heat engine of the Quaternary. Proceedings of the $17^{\text {th }}$ INQUA Congress, Cairns, Australia (28.07.-03.08.2007).- Elsevier, 43-44, Amsterdam.

Brunet-Lecomte, P. \& B. Kryštufek, 1993: Evolutionary divergence of Microtus liechtensteini (Rodentia, Arvicolidae) based on the first lower molar.- Acta Theriologica, 38, 3, 297-304, Białowieża.

Culiberg, M., 1995: Dezertifikacija in reforestacija slovenskega Krasa. Desertification and reforestation of the Karst in Slovenia.- Poročilo o raziskovanju paleolitika, neolitika in eneolitika v Sloveniji, 22, 201215, Ljubljana.

Cremonesi, G., Meluzzi, C., Pitti, C. \& B. Wilkens, 1984: Grotta Azzurra: scavi 1982 (Nota preliminare).- In: Il Mesolitico sul Carso Triestino, Società per la Preistoria e Protostoria della Regione Friuli-Venezia Giulia, Quaderno, 5. - Edizioni “Italo Svevo”, 21-64, Trieste.

Filippucci, M.G., Storch, G. \& M. Macholan, 1996: Taxonomy of the genus Sylvaemus in western Anatolia - morphological and electrophoretic evidence (Mammalia: Rodentia: Muridae).- Senckenbergiana biologica, 75, 1/2, 1-14, Frankfurt.

Fladerer, F.A., 2000: Late Quaternary vertebrate taphocoenoses from cave deposits in southeastern Austria: responses in a periglacial setting. - In: Hart, M.B. (ed.), Climates: past and present. Special Publications, 181. Geological Society, 199-213, London.

Grayson, D.K., 1984: Quantitative zooarchaeology.- Academic Press, Inc., p. 202, Orlando etc.

Hagmeier, E.M. \& C.D. Stults, 1964: A numerical analysis of the distributional patterns of North American mammals.- Systematic Zoology, 13, 125-155, Washington.

Haring, E., Herzig-Straschil, B. \& F. Spizenberger, 2000: Phylogenetic analysis of Alpine voles of the Microtus multiplex complex using the mitochondrial control region.- Journal of zoological systematics and evolutionary research, 38, 231-238, Berlin.

Hír, J., 1993: Cricetulus migratorius (Pallas 1773) (Rodentia, Mammalia) population from the Toros Mountains (Turkey) (with a special reference to the relation of Cricetulus and Allocricetus genera).- Folia historico-naturalia Musei Matraensis, 18, 17-34, Gyöngyös. 
Hutterer, R., 1999: Sorex minutus Linneaus, 1766. - In: Mitchell-Jones, A.J., Amori, G., Bogdanowicz, W., Kryštufek, B., Reijnders, P.J.H., Spitzenberger, F., Stubbe, M., Thissen, J.B.M., Vohralík, V. \& J. Zima, (eds.), The atlas of European mammals, Poyser Natural History.- T. \& A.D. Poyser, 54-55, London.

Janžekovič, F. \& M. Čas, 2001: Mali sesalci v gozdni krajini in pestrost njihove združbe $\mathrm{v}$ alpskem gozdu na Smrekovcu in Peci.- Gozdarski vestnik, 59, 7-8, 322-327, Ljubljana.

Janžekovič, F. \& B. Kryštufek, 2004: Geometric morphometry of the upper molars in European wood mice Apodemus.- Folia Zoologica, 53, 1, 47-55, Praha.

Karajić, A. \& B. Kryštufek, 1999: Sesalci (Mammalia) Brkinov.- Annales, 15, Series historia naturalis 9, 1, 101-110, Koper.

Kryštufek, B., 1986: Variability of enamel tooth pattern in Microtus arvalis from Dalmatia (Rodentia, Mammalia).- Biološki vestnik, 34, 2, 37-42, Ljubljana.

Kryštufek, B., 1990: Geographic variation in Microtus nivalis (Martins, 1842) from Austria and Yugoslavia.Bonner Zoologische Beiträge, 41, 2, 121-139, Bonn.

Kryštufek, B., 1991: Sesalci Slovenije.- Prirodoslovni muzej Slovenije, p. 294, Ljubljana.

Kryštufek, B., 1997: Mali sesalci (Insectivora, Chiroptera, Rodentia). Small Mammals (Insectivora, Chiroptera, Rodentia.)- In: Turk, I. (ed.), Moustérienska »koščena piščal in druge najdbe iz Divjih bab I $v$ Sloveniji. Mousterian "bone flute" and other finds from Divje babe I cave site in Slovenia, Opera Instituti Archaeologici Sloveniae, 2. - Založba ZRC, 8598, Ljubljana.

Kryštufek, B., 1999: Microtus subterraneus (de SélysLongchamps, 1836).- In: Mitchell-Jones, A.J., Amori, G., Bogdanowicz, W., Kryštufek, B., Reijnders, P.J.H., Spitzenberger, F., Stubbe, M., Thissen, J.B.M., Vohralík, V. \& J., Zima (eds.), The atlas of European mammals, Poyser Natural History. T. \& A.D. Poyser, 250-251, London.

Kryštufek, B., 2004: A quantitative assessment of Balkan mammal diversity.- In: Griffiths, H.I., B. Kryštufek \& J.M. Reed (eds.), Balkan biodiversity: pattern and process in the European hotspot. Kluwer Academic, 79-108, Dordrecht, London.

Kryštufek, B., Buzan, E.V., Hutchinson, W.F. \& B. Hänfling, 2007: Phylogeography of the rare Balkan endemic Martino's vole, Dinaromys bogdanovi, reveals strong differentiation within the western Balkan Peninsula.- Molecular Ecology, 16, 1221-1232, Oxford.
Kryštufek, B. \& H. Griffiths, 1999: Mediterranean v. continental small mammal communities and the environmental degradation of the Dinaric Alps.- Journal of Biogeography, 26, 1, 167-177, Oxford.

Kryštufek, B. \& L. Lipej, 2002: Žužkojedi in glodalci doline Dragonje in njihovo naravovarstveno ovrednotenje.- Varstvo narave, 19, 59-67, Ljubljana.

Kryštufek, B. \& V. Vohralík, 2005: Mammals of Turkey and Cyprus. Rodentia I: Sciurudae, Dipododae, Gliridae, Arvicolinae. - Založba Annales, p. 292, Koper.

Leben, F., 1988: Novoodkrite prazgodovinske plasti v jamah na Krasu. Die neuentdeckten vorgeschichtlichen Schichten in den Karsthöhlen.- Poročilo o raziskovanju paleolita, neolita in eneolita v Sloveniji, 16, 65-76, Ljubljana.

Lipej, L. \& M. Gjerkeš, 1996: Diet of the tawny owl (Strix aluco) in the karst environment near Škocjanske jame (SW Slovenia).- Acta carsologica, 25, 351-363, Ljubljana.

Mauch Lenardić, J., 2005: Metrijska I morfometska analiza zuba gornjepleistocenskih voluharica Hrvatske.Ph.D. thesis, University of Zagreb, p. 166, Zagreb.

Mayhew, D.F., 1978: Late Pleistocene small mammals from Arnissa (Macedonia, Greece).- Proceedings of the Koninklijke Nederlandse Academie van Watenschappen, Series B, 81, 3, 302-321, Amsterdam.

Meluzzi, C., Pitti, C., Radmilli, A.M. \& B. Wilkens, 1984: Il mesolitico della Grotta Lonza.- In: Il Mesolitico sul Carso Triestino, Società per la Preistoria e Protostoria della Regione Friuli-Venezia Giulia, Quaderno, 5. Edizioni “Italo Svevo", 109-130, Trieste.

Montagnari Kokelj, E., 1984: La grotta VG 4245 di Trebiciano (Trieste).- In: Il Mesolitico sul Carso Triestino, Società per la Preistoria e Protostoria della Regione Friuli-Venezia Giulia, Quaderno, 5. Edizioni "Italo Svevo", 211-228, Trieste.

Montgomery, W.I., 1999: Apodemus flavicollis (Melchior, 1834). ).- In: Mitchell-Jones, A.J., Amori, G., Bogdanowicz, W, Kryštufek, B., Reijnders, P.J.H., Spitzenberger, F., Stubbe, M., Thissen, J.B.M., Vohralík, V. \& J. Zima (eds.), The atlas of European mammals, Poyser Natural History.- T. \& A.D. Poyser, 270-271, London.

Nadachowski, A., 1984: Taxonomic value of anteroconid measurements of $M_{1}$ in common and field voles.Acta Theriologica, 29, 10, 123-143, Białowieża.

Niethammer, J. \& F. Krapp (eds.), 1978: Handbuch der Säugetiere Europas, Band 1.- Akademische Verlagsgesellschaft, p. 476, Wiesbaden.

Niethammer, J. \& F. Krapp (eds.), 1982: Handbuch der Säugetiere Europas. Band 2/I- Akademische Verlagsgesellschaft, p. 649, Wiesbaden. 
Petrov, B. \& M. Todorović, 1982: Dinaromys bogdanovi (V. et E. Martino, 1922) - Bergmaus.- In: Niethammer, J. \& F., Krapp (eds), Handuch der Säugetiere Europas, Band 2/I.- Akademische Verlagsgesellschaft, 193-208, Wiesbaden.

Pohar, V., 1984: Favnistični ostanki mezolitske postaje na prostem Breg-Škofljica pri Ljubljani.- Poročilo o raziskovanju paleolita, neolita in eneolita v Sloveniji, 12, 7-27, Ljubljana.

Pohar, V., 1986: Kostni ostanki mezolitskega najdišča Pod Črmukljo pri Šembijah (Ilirska Bistrica). Knochenreste aus dem mesolitischen Fundort Pod Črmukljo bei Šembije (Ilirska Bistrica).- Poročilo o raziskovanju paleolita, neolita in eneolita v Sloveniji, 14, 11-20, Ljubljana.

Pohar, V., 1990: Sesalska makrofavna v starejšem holocenu. Die Säuger-Makrofauna im älteren Holozän.Poročilo o raziskovanju paleolita, neolita in eneolita v Sloveniji, 18, 43-49, Ljubljana.

Popov, V.V., 1989: Middle Pleistocene small mammals (Insectivora, Lagomorpha, Rodentia) from Morovitsa Cave (North Bulgaria).- Acta zoological cracoviensia, 32, 13, 561-588, Kraków.

Popov, V.V., 1994: Quaternary small mammals from deposits in Temnata-Prohodna Cave system.- In: Ginter, B., Kozłowski, J.K. \& H. Laville, (eds.), Temnata Cave. Excavations in Karlukovo karst area.Jagellonian University Press, p. 501, Kraków.

Rabeder, G., 2004: Micro-mammals from Pleistocene sediments of Potočka zijalka (Slovenia). - In: Pacher, M., Pohar, V. \& G. Rabeder (eds.), Potočka Zijalka: palaeontological and archaeological results of the campaigns 1997-2000, Mitteilungen der Kommission für Quartärforschung der Österreichischen Akademie der Wissenschaften, 13. Verlag der Österreichischen Akademie der Wissenschaften, 5566 , Wien.

Rakovec, I., 1959: Kvartarna sesalska favna iz Betalovega spodmola pri Postojni. The Quaternary mammalian fauna from the cave Betalov spodmol near Postojna.- Razprave IV. razreda SAZU, 5, 289-348, Ljubljana.

Rakovec, I., 1961: Mladopleistocenska favna iz Parske golobine $\mathrm{v}$ Pivški kotlini. The Upper Pleistocene fauna from the cave Parska golobina (in the Pivka basin).Razprave IV. razreda SAZU, 6, 273-349, Ljubljana.

Rosenzweig, M.L., 1996: Species diversity in space and time.- Cambridge University, 436, Cambridge.

Spitzenberger, F., Brunet-Lecomte, P., Nadachowski, A. \& K. Bauer, 2000: Comparative morphometrics of the first lower molar in Microtus (Terricola) cf. liechtensteini of the Eastern Alps.- Acta Theriologica, 45, 4, 471-483, Białowieża.
StatSoft, Inc., 2001: Statistica (data analysis software system), version 6. [Online]. Available from http:// statsoft.com (Accessed on $15^{\text {th }}$ January 2008)

Tchernov, E., 1968: Succession of rodent faunas during the Upper Pleistocene of Israel.- Verlag Paul Parey, p. 152, Hamburg.

Terzea, E., 1972: Remarques sur la morphologie dentaire et la répartition de Microtus nivalis Martins dans le Pléistocène de Roumanie.- Travaux de l'Institut de spéologie "Émile Racovitza", 11, 271-298, Bucureşti.

Toškan, B. \& J. Dirjec, 2004: Ostanki velikih sesalcev v Viktorjevem spodmolu. Remains of large mammals in Viktorjev spodmol.- In: Turk, I. (ed.), Viktorjev spodmol in Mala Triglavca. Prispevki k poznavanju mezolitskega obdobja v Sloveniji. Viktorjev spodmol and Mala Triglavca. Contributions to understanding the Mesolithic period in Slovenia, Opera Instituti Archaeologici Sloveniae, 9. Založba ZRC, 135-167, Ljubljana.

Toškan, B. \& J. Dirjec, 2006: Veliki sesalci. Large mammals.- In: Gaspari, A. (ed.), Zalog pri Verdu, tabor kamenodobnih lovcev na zahodnem robu Ljubljanskega barja. Zalog near Verd, Stone Age hunters' camp at the western edge of the Ljubljansko barje, Opera Instituti Archaeologici Sloveniae, 11. Založba ZRC, 165-188, Ljubljana.

Toškan, B. \& B. Kryštufek, 2004: Ostanki malih sesalcev (Insectivora, Chiroptera, Rodentia) v Viktorjevem spodmolu. Small mammals (Insectivora, Chiroptera, Rodentia) in Viktorjev spodmol.- In: Turk, I. (ed.), Viktorjev spodmol in Mala Triglavca. Prispevki k poznavanju mezolitskega obdobja v Sloveniji. Viktorjev spodmol and Mala Triglavca. Contributions to understanding the Mesolithic period in Slovenia, Opera Instituti Archaeologici Sloveniae, 9. Založba ZRC, 114-134, Ljubljana.

Toškan, B. \& B. Kryštufek, 2006: Noteworthy rodent records from the Upper Pleistocene and Holocene of Slovenia.- Mammalia, 70, 1, 2, 98-105, Berlin, New York.

Toškan, B. \& B. Kryštufek, 2007: Mali terestrični sesalci (Erinaceomorpha, Soricomorpha, Chiroptera, Rodentia) iz Divjih bab I. Small terrestrial mammals (Erinaceomorpha, Soricomorpha, Chiroptera, Rodentia) from Divje babe I.- In: Turk, I. (ed.), Divje babe I. Paleolitsko najdišče mlajšega pleistocena $v$ Sloveniji. I. del: Geologija in paleontologija. Divje babe I. Upper Pleistocene Palaeolithic site in Slovenia. Part I: Geology and palaeontology, Opera Instituti Archaeologici Sloveniae, 13. Založba ZRC, 193219, Ljubljana. 
Turk, I., 2004a: Uvod. Introduction.- In: Turk, I. (ed.), Viktorjev spodmol in Mala Triglavca. Prispevki $k$ poznavanju mezolitskega obdobja $v$ Sloveniji. Viktorjev spodmol and Mala Triglavca. Contributions to understanding the Mesolithic period in Slovenia, Opera Instituti Archaeologici Sloveniae, 9. Založba ZRC, 173-175, Ljubljana.

Turk, I., 2004b: Sklep. Conclusion.- In: Turk, I. (ed.), Viktorjev spodmol in Mala Triglavca. Prispevki $k$ poznavanju mezolitskega obdobja $v$ Sloveniji. Viktorjev spodmol and Mala Triglavca. Contributions to understanding the Mesolithic period in Slovenia, Opera Instituti Archaeologici Sloveniae, 9. Založba ZRC, 207-210, Ljubljana.

Turk, I., Toškan, B. \& J. Dirjec, 2004: Sesalska favna. Mammalian fauna.- In: Turk, I. (ed.), Viktorjev spodmol in Mala Triglavca. Prispevki k poznavanju mezolitskega obdobja $v$ Sloveniji. Viktorjev spodmol and Mala Triglavca. Contributions to understanding the Mesolithic period in Slovenia, Opera Instituti Archaeologici Sloveniae, 9. Založba ZRC, 201-203, Ljubljana.

Turk, I. \& A., Velušček, 2004: Najdbe keramike. Finds of pottery.- In: Turk, I. (ed.), Viktorjev spodmol in Mala Triglavca. Prispevki k poznavanju mezolitskega obdobja v Sloveniji. Viktorjev spodmol and Mala Triglavca. Contributions to understanding the Mesolithic period in Slovenia, Opera Instituti Archaeologici Sloveniae, 9. Založba ZRC, 87, Ljubljana.
Turk, M. \& I. Turk, 2004: Arheološke najdbe. Archaeological finds.- In: Turk, I. (ed.), Viktorjev spodmol in Mala Triglavca. Prispevki k poznavanju mezolitskega obdobja v Sloveniji. Viktorjev spodmol and Mala Triglavca. Contributions to understanding the Mesolithic period in Slovenia, Opera Instituti Archaeologici Sloveniae, 9. Založba ZRC, 176-196, Ljubljana.

Urbańczyk, Z., 1999: Barbastella barbastellus (Schreber, 1774).- In: Mitchell-Jones, A.J., Amori, G., Bogdanowicz, W., Kryštufek, B., Reijnders, P.J.H., Spitzenberger, F., Stubbe, M., Thissen, J.B.M., Vohralík, V. \& J. Zima (eds.), The atlas of European mammals, Poyser Natural History.- T. \& A.D. Poyser, 146-147, London.

Van Der Meulen, A.J., 1973: Middle Pleistocene smaller mammals from Monte Peglia. (Orveto, Italy) with special reference to the phylogeny of Microtus (Arvicolidae, Rodentia).- Quaternaria, 17, 1-144, Roma.

Wilson, D.E. \& D.M. Reeder (eds.), 2005: Mammal species of the world.- John Hopkins University Press, Baltimore. 
SMALL TERRESTRIAL MAMMALS (SORICOMORPHA, CHIROPTERA, RODENTIA) FROM THE EARLY HOLOCENE LAYERS ...

\begin{tabular}{|c|c|c|c|c|c|}
\hline \multicolumn{6}{|c|}{ Apodemus flavicollis/sylvaticus/agrarius: M1 length $\mathrm{x}$ breadth } \\
\hline $1.76 \times 1.20$ & $1.95 \times 1.32$ & $2.08 \times 1.32$ & $1.89 \times 1.26$ & $1.89 \times 1.32$ & $2.02 \times 1.20$ \\
\hline $1.83 \times 1.20$ & $1.89 \times 1.32$ & $1.95 \times 1.32$ & $1.89 \times 1.32$ & $1.83 \times 1.20$ & $1.76 \times 1.20$ \\
\hline $2.02 \times 1.26$ & $1.83 \times 1.26$ & $2.02 \times 1.32$ & $1.89 \times 1.32$ & $1.95 \times 1.26$ & $2.02 \times 1.32$ \\
\hline $1.89 \times 1.26$ & $2.02 \times 1.32$ & $2.02 \times 1.32$ & $2.08 \times 1.39$ & $1.83 \times 1.26$ & $1.95 \times 1.39$ \\
\hline $2.02 \times 1.39$ & $2.02 \times 1.26$ & $1.95 \times 1.26$ & $2.02 \times 1.26$ & $1.95 \times 1.26$ & $1.89 \times 1.32$ \\
\hline $1.95 \times 1.26$ & $2.2 \times 1.26$ & $1.76 \times 1.26$ & $2.02 \times 1.26$ & $1.95 \times 1.20$ & $1.95 \times 1.32$ \\
\hline $2.02 \times 1.32$ & $2.02 \times 1.26$ & $1.70 \times 1.26$ & $1.95 \times 1.32$ & $2.14 \times 1.26$ & $1.95 \times 1.20$ \\
\hline $1.89 \times 1.26$ & $2.02 \times 1.26$ & $2.02 \times 1.26$ & $1.89 \times 1.20$ & $2.08 \times 1.32$ & $2.08 \times 1.32$ \\
\hline $1.89 \times 1.26$ & $2.02 \times 1.26$ & $1.95 \times 1.20$ & $1.89 \times 1.20$ & $1.89 \times 1.20$ & $1.95 \times 1.20$ \\
\hline $1.95 \times 1.32$ & $1.89 \times 1.20$ & $1.95 \times 1.32$ & $2.08 \times 1.32$ & $1.83 \times 1.20$ & $1.89 \times 1.26$ \\
\hline $2.14 \times 1.32$ & $2.02 \times 1.32$ & $2.02 \times 1.32$ & $2.08 \times 1.39$ & $1.83 \times 1.26$ & $1.95 \times 1.32$ \\
\hline $1.95 \times 1.26$ & $1.89 \times 1.32$ & $1.89 \times 1.32$ & $2.08 \times 1.26$ & $1.95 \times 1.26$ & $1.89 \times 1.26$ \\
\hline $2.21 \times 1.39$ & $1.95 \times 1.32$ & $2.08 \times 1.32$ & $2.02 \times 1.26$ & $1.89 \times 1.26$ & $2.14 \times 1.32$ \\
\hline $1.89 \times 1.32$ & $1.95 \times 1.26$ & $2.02 \times 1.26$ & $2.08 \times 1.26$ & $1.95 \times 1.32$ & $1.95 \times 1.26$ \\
\hline $1.89 \times 1.26$ & $2.14 \times 1.26$ & & & & \\
\hline \multicolumn{6}{|c|}{ Microtus agrestis/arvalis: $\mathrm{m} 1$ length } \\
\hline 2.71 & 2.39 & 2.90 & 2.90 & 2.52 & 2.65 \\
\hline \multicolumn{6}{|c|}{ Microtus subterraneus/liechtensteini: $\mathrm{m} 1$ length } \\
\hline 2.58 & 2.46 & 2.39 & 2.33 & 2.27 & 2.33 \\
\hline 2.77 & 2.46 & 2.39 & 2.46 & 2.39 & 2.65 \\
\hline 2.39 & 2.33 & 2.58 & & & \\
\hline \multicolumn{6}{|c|}{ Myodes glareolus: $\mathrm{m} 1$ length } \\
\hline 2.52 & 2.46 & 2.39 & 2.33 & 2.58 & 2.27 \\
\hline 2.52 & 2.52 & 2.46 & 2.33 & 2.33 & \\
\hline \multicolumn{6}{|c|}{ Glis glis: $\mathrm{m} 1$ length $\mathrm{x}$ breadth } \\
\hline $2.08 \times 2.14$ & $2.02 \times 1.89$ & $2.08 \times 2.08$ & $1.95 \times 1.89$ & $1.95 \times 1.89$ & $2.08 \times 1.95$ \\
\hline $2.27 \times 2.14$ & $2.14 \times 1.95$ & $2.08 \times 2.02$ & $2.14 \times 2.08$ & $2.08 \times 2.08$ & $2.21 \times 2.02$ \\
\hline $2.08 \times 1.95$ & $2.02 \times 2.02$ & $2.02 \times 2.02$ & $2.14 \times 2.08$ & $2.21 \times 2.14$ & $2.21 \times 2.08$ \\
\hline $2.21 \times 2.14$ & $2.21 \times 2.02$ & $2.08 \times 2.02$ & $2.27 \times 2.21$ & $1.95 \times 1.83$ & $2.02 \times 2.08$ \\
\hline $2.08 \times 2.02$ & $1.95 \times 1.83$ & $2.33 \times 2.02$ & $2.14 \times 2.02$ & $2.27 \times 2.02$ & $2.14 \times 2.08$ \\
\hline $2.14 \times 2.08$ & $2.14 \times 2.08$ & $2.08 \times 2.02$ & $2.21 \times 2.14$ & & \\
\hline
\end{tabular}

Annex 1: Measurements (in $\mathrm{mm}$ ) of the small mammal remains from Early Holocene sediments of M. Triglavca. 
